tance in evolution until environmental stress is placed on the population containing these mutations, and this stress need not be in the form of competition between individuals because of overpopulation. If the microbial population containing penicillin-resistant organisms is never subjected to penicillin, and assuming there is no other effect of this mutation on the organism, is there evolution toward a penicillin-resistant population?

Whyte further states, "Adaptive selection depends on a high death rate and expresses competition,..." $\mathrm{He}$ is in error if he believes that this is the dominant principle inherent in the synthetic theory of evolution.

After two chapters given to a historical review of the conccpts upon which he formulates his views, and a pointed attack on the inability of leading evolutionists to understand them, he arrives at twelve conclusions put forward for the consideration of the specialist, which are more or less of a summary of the notions already expressed.
The concluding chapter expresses the hope that the theory of internal factors in evolution will some day be vindicated, and that a "fresh chapter in the history of ideas will be opened and biology will be guided by a new paradigm."

In a weak and ill-supported effort to deemphasize the role of natural selection in evolution Whyte has detracted from what could have been a fine analysis and philosophical discussion of the latest advances in the chemical basis of heredity and evolution. His strongest arguments are his own misrepresentations of the prevalent theory of evolution.

Perhaps Whyte will add this reviewer to the long list of those who do not understand him, and perhaps he is justified in so doing. However, it is felt that if Whyte had a broader understanding of the theory of evolution as it is discussed in the leading texts on the subject, he would also understand why he alone has written this book.Robert E. Hillman University of Maryland Chesapeake Biological Laboratory Solomons, Maryland

\title{
Errata Note
}

Entries in Table 1 of the paper "Condition of the quahog, Mercenaria mercenaria, from polluted and unpolluted waters," Vol. 5, No. 4, pp. 155160, should read:

\author{
$\mathrm{PO}_{4}-\mathrm{P} \mu \mathrm{g}$ at $/ \mathrm{L}$ \\ Total $\mathrm{P} \mu \mathrm{g}$ at $/ \mathrm{L}$ \\ Coliform bacteria ${ }^{1}$ \\ no. $/ \mathrm{L} \times 10^{2}$
}

